\title{
Distribution characteristics and potential risk assessment of heavy metals in seawater and sediment of Liaodong Bay
}

\author{
Nianting Si, Liang Qu* \\ China National Offshore Oil Corporation China Limited, Tianjin, 300459 Tianjin, China
}

\begin{abstract}
Distribution of heavy metals $(\mathrm{Hg}, \mathrm{Cu}, \mathrm{Pb}, \mathrm{Zn}, \mathrm{Cd}$ and $\mathrm{Cr})$ in the seawater and sediments were studied based on data from two oceanographic surveys carried out in Liaodong Bay in May and October 2016. The results showed that the values of heavy metals in seawater represent a uniform distribution, while no trends were detected for spatial distribution. High values of heavy metals in sediment were generally distributed nearshore areas in October. Concentrations of $\mathrm{Pb}, \mathrm{Zn}, \mathrm{Hg}$ in seawater were higher than the national guideline values of Mar. sediment quality of China. Values of $\mathrm{Cu}, \mathrm{Zn}, \mathrm{Cd}$ and $\mathrm{Hg}$ were higher than the national guideline values of Mar. sediment quality of China in October, while quality was in good condition in May. Correlation analysis showed that TOC was mainly contributed for the variations of heavy metals. The potential ecological risk analysis of heavy metals indicates that $\mathrm{Hg}, \mathrm{Cd}$ and $\mathrm{Cu}$ should be listed as the priority contaminant metals in Liaodong Bay.
\end{abstract}

\section{Introduction}

Liaodong Bay, in the northeast part of the Bohai Sea, is a semi-enclosed bay. Along with the development of urban economy in the areas surrounding the Liaodong Bay, there are increasing amounts of pollutants day by day, and the circulation of such pollutants into the waters of Liaodong Bay through rivers, atmospheric deposition, waterway transportation and other approaches has caused potential harm to the ecological environment of the Liaodong Bay ${ }^{[1]}$. Heavy metals in waters can, transferred and accumulated through the food chain, generate toxic effects on the growth of individual organisms, and then affect the function of Mar. ecosystem and human health ${ }^{[2,3]}$. Meanwhile, heavy metals can be part of the sediments during the adsorption process, and since the sediments are only slightly affected by hydrological factors, it's easy for heavy metals to store up in the sediments and pollute the benthic environment ${ }^{[4,5]}$. In terms of the heavy metal pollution in the Liaodong Bay, a series of researches and studies have been carried out, and through which people finally have a certain understanding of the heavy metal pollution in this area ${ }^{[6,7,8,9]}$. The earlier researches show that the changes of heavy metal content in the sediments of Liaodong Bay is mainly related to the grain size and clay content of the sediments ${ }^{[10]}$. In recent years, some scholars, by analysing the potential ecological risk and Environ. quality of Liaodong Bay due to the existence of heavy metals, find that cadmium and mercury are the main pollutants of heavy metals in the sediments of Liaodong Bay ${ }^{[11]}$. Some scholars discover that concentration of heavy metal pollutants in the rivers flowing from the Liaodong Bay to the Haihe River is much higher than that in the coastal sea areas, and mercury and lead - the heavy metals in the sediments are of medium and high ecological risk ${ }^{[12]}$. After long-term monitoring and analysis, some scholars also find that terrestrial input plays a major role in studying the changes of heavy metal content in Mar. sediments ${ }^{[13]}$.

Till now, most researches conducted in Liaodong Bay simply focus on spatial and temporal changes of heavy metals in a single environment, and there are very few studies on the spatial and temporal changes of heavy metals from the aspects of water environment and sediment substratum. The main objectives of this study were: (1) detect the temporal and spatial distribution of heavy metals in sea water and surface sediments of Liaodong Bay; (2) discuss the corresponding controlling factors; (3) assess the environmental risk; (4) evaluate the heavy metal pollution status.

\section{Materials and methods}

\subsection{Study area}

Oceanographic surveys have been carried out respectively in May 2016 and October 2016, with the position of survey stations shown in Figure 1.

\footnotetext{
* Corresponding author: quliang2@cnooc.com.cn
} 


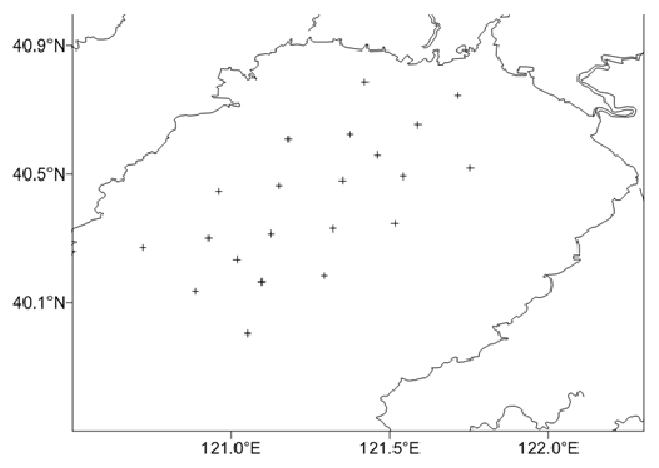

Fig.1. Investigation sea area and survey sites

\subsection{Sample collection and measurement}

Seawater samples are collected via Niskin water samples from the sampling depth: the surface layer $(0.5 \mathrm{~m}$ below the surface layer), $10 \mathrm{~m}$ layer and bottom layer $(2 \mathrm{~m}$ higher than the mud line). Sediment samples are collected from the surface layer by using dawn type mud samplers. The collection, storage, transportation and analysis of samples have been carried out in accordance with The Specification for Marine Monitoring (GB 17378-2007) and Specifications for Oceanographic Survey (GB 12763-2007), with the analytical methods shown in Table 1.

Table 1. Methods of analysis

\begin{tabular}{|c|c|c|c|}
\hline Type & Item & Analytical Method & Specifications \\
\hline \multirow{6}{*}{ Seawater } & $\begin{array}{l}\text { Mercury } \\
(\mathrm{Hg})\end{array}$ & $\begin{array}{l}\text { Atomic fluorescence } \\
\text { spectrometry }\end{array}$ & \multirow{6}{*}{$\begin{array}{c}\text { GB17378.4- } \\
2007\end{array}$} \\
\hline & $\begin{array}{l}\text { Copper } \\
\text { (Cu) }\end{array}$ & $\begin{array}{l}\text { Atomic absorption } \\
\text { spectrometry }\end{array}$ & \\
\hline & $\begin{array}{l}\text { Lead } \\
(\mathrm{Pb})\end{array}$ & $\begin{array}{l}\text { Atomic absorption } \\
\text { spectrometry }\end{array}$ & \\
\hline & $\begin{array}{l}\text { Zinc } \\
(\mathrm{Zn})\end{array}$ & $\begin{array}{l}\text { Atomic absorption } \\
\text { spectrometry }\end{array}$ & \\
\hline & $\begin{array}{l}\text { Cadmium } \\
\quad(\mathrm{Cd})\end{array}$ & $\begin{array}{l}\text { Atomic absorption } \\
\text { spectrometry }\end{array}$ & \\
\hline & $\begin{array}{l}\text { Chromium } \\
\text { (Cr) }\end{array}$ & $\begin{array}{l}\text { Atomic absorption } \\
\text { spectrometry }\end{array}$ & \\
\hline \multirow{7}{*}{ Sediments } & $\begin{array}{l}\text { Cadmium } \\
\quad(\mathrm{Cd})\end{array}$ & $\begin{array}{l}\text { Atomic fluorescence } \\
\text { spectrometry }\end{array}$ & \multirow{7}{*}{$\begin{array}{c}\text { GB17378.5- } \\
2007\end{array}$} \\
\hline & $\begin{array}{l}\text { Zinc } \\
(\mathrm{Zn})\end{array}$ & $\begin{array}{l}\text { Atomic absorption } \\
\text { spectrometry }\end{array}$ & \\
\hline & $\begin{array}{c}\text { Lead } \\
(\mathrm{Pb})\end{array}$ & $\begin{array}{l}\text { Atomic absorption } \\
\text { spectrometry }\end{array}$ & \\
\hline & $\begin{array}{l}\text { Copper } \\
\text { (Cu) }\end{array}$ & $\begin{array}{l}\text { Atomic absorption } \\
\text { spectrometry }\end{array}$ & \\
\hline & $\begin{array}{l}\text { Cadmium } \\
\quad(\mathrm{Cd})\end{array}$ & $\begin{array}{l}\text { Atomic absorption } \\
\text { spectrometry }\end{array}$ & \\
\hline & $\begin{array}{l}\text { Chromium } \\
\text { (Cr) }\end{array}$ & $\begin{array}{l}\text { Atomic absorption } \\
\text { spectrometry }\end{array}$ & \\
\hline & $\begin{array}{c}\text { Organic } \\
\text { Carbon } \\
(\mathrm{OC})\end{array}$ & $\begin{array}{l}\text { Elemental analyzer } \\
\text { method }\end{array}$ & \\
\hline
\end{tabular}

\subsection{Evaluation of single factor standard index for heavy metal content}

Single factor standard index method has been used to evaluate the quality situation of heavy metals, with the computational formula being:

$$
\mathrm{Ii}=\mathrm{Ci} / \mathrm{Si}
$$

In which, Ii refers to the standard index of the ith heavy metal, $C_{i}$ refers to the measured value of the ith heavy metal, $S_{i}$ refers to the first-class standard value of the ith heavy metal. When $I_{i} \leq 1$, the result is up to the standard; and when $I_{i}>1$, the content exceeds the standard.

\subsection{Evaluation of potential ecological risk index of heavy metals in sediments}

In this paper, heavy metal potential ecological risk index evaluation method [14] is adopted to evaluate the pollution and ecological hazards of heavy metals in the survey sea areas by applying the potential ecological risk factor of single heavy metal, with the computational formula being:

$$
E_{r}^{i}=T_{r}^{i} \times C_{f}^{i}=T_{r}^{i} \times C_{i} / C_{n}^{i}
$$

In which, Eri refers to the potential ecological risk factor of heavy metal $i$; $T_{r}^{i}$ refers to the toxicity response coefficient of heavy metal $i$, which can reflect the toxicity level of heavy metal $i$ and the sensitivity degree of organisms to pollutants; $C_{f}^{i}$ refers to the contamination factor of heavy metal $i$; $C_{i}$ refers to the measured concentration of heavy metal $i ; C_{n}{ }^{i}$ refers to the background reference value of heavy metal $i$. In this paper, the background values proposed by Feng et al.2003 are adopted as the grading values ${ }^{[15]}$ (Table 2).

Table 2. Toxicity response coefficient and background reference values of heavy metals

\begin{tabular}{ccccccc}
\hline \multirow{2}{*}{ Item } & \multicolumn{6}{c}{ Heavy metals } \\
\cline { 2 - 7 } & $\mathrm{Hg}$ & $\mathrm{Cu}$ & $\mathrm{Pb}$ & $\mathrm{Cd}$ & $\mathrm{Zn}$ & $\mathrm{Cr}$ \\
\hline$T_{r}{ }^{i}$ & 40 & 5 & 5 & 30 & 1 & 2 \\
\hline$C_{n}{ }^{i}\left(10^{-6}\right)$ & 0.25 & 50 & 70 & 1 & 175 & 90 \\
\hline
\end{tabular}

\subsection{Statistical analysis}

Surfer11.0 software is used to draw the distribution map of heavy metals in surface seawater and surface sediments, and SPSS13.0 is adopted to carry out significance test and correlation analysis.

\section{Results and discussion}

\subsection{Distribution characteristics of heavy metals in seawater}

The measured results of heavy metals in seawater samples from the survey sea area are shown in Table 3. 
The average values of heavy metals at different depth of water in May are respectively, $\mathrm{Cu}: 1.80,1.68$ and $1.94 \mu \mathrm{g}$ $\mathrm{L}^{-1} ; \mathrm{Pb}: 1.42,1.43,1.34 \mu \mathrm{g} \mathrm{L}^{-1} ; \mathrm{Zn}: 15.46,15.43$ and

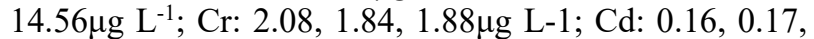
$0.15 \mu \mathrm{g} \mathrm{L}{ }^{-1}$; Hg: $0.066,0.047,0.065 \mu \mathrm{g}$ L-1. The average content values of heavy metals at different depth of water in October are respectively, $\mathrm{Cu}: 1.84,1.69$ and $1.82 \mu \mathrm{g} \mathrm{L}{ }^{-1} ; \mathrm{Pb}: 1.34,1.38,1.45 \mu \mathrm{g} \mathrm{L}^{-1} ; \mathrm{Zn}: 13.96,15.37$ and $15.11 \mu \mathrm{g} \mathrm{L}^{-1}$; Cr: $2.02,1.87,1.95 \mu \mathrm{g} \mathrm{L} \mathrm{L}^{-1}$; Cd: 0.16 , 0.15, $0.15 \mu \mathrm{g} \mathrm{L} \mathrm{L}^{-1}$; $\mathrm{Hg}: 0.042,0.042,0.045 \mu \mathrm{g} \mathrm{L} \mathrm{L}^{-1}$.

Table 3. Concentrations of heavy metals in seawater $\left(\mu \mathrm{g} \mathrm{L}^{-1}\right)$

\begin{tabular}{|c|c|c|c|c|c|c|c|c|}
\hline Time & Depth & Value & $\mathrm{Cu}$ & $\mathrm{Pb}$ & $\mathrm{Zn}$ & $\mathrm{Cr}$ & $\mathrm{Cd}$ & $\mathrm{Hg}$ \\
\hline \multirow{6}{*}{ May } & \multirow{2}{*}{$\begin{array}{l}\text { Surface } \\
\text { layer }\end{array}$} & Scope & $0.84-2.58$ & $0.66-2.36$ & $8.35-22.80$ & $1.05-2.88$ & $0.087-0.23$ & $0.014-0.18$ \\
\hline & & Average & 1.80 & 1.42 & 15.46 & 2.08 & 0.16 & 0.066 \\
\hline & \multirow[t]{2}{*}{$10 \mathrm{~m}$} & Scope & $0.93-2.78$ & $0.73-2.12$ & $9.15-21.80$ & $0.94-2.87$ & $0.083-0.23$ & $0.019-0.097$ \\
\hline & & Average & 1.08 & 1.43 & 15.43 & & & \\
\hline & \multirow{2}{*}{$\begin{array}{c}\text { Bottom } \\
\text { layer }\end{array}$} & Scope & $0.96-2.78$ & $0.64-2.15$ & $8.07-23.50$ & $0.97-2.80$ & $0.086-0.23$ & $0.015-0.16$ \\
\hline & & Average & 1.94 & 1.34 & 14.56 & 1.88 & 0.15 & 0.065 \\
\hline \multirow{6}{*}{ October } & \multirow{2}{*}{$\begin{array}{l}\text { Surface } \\
\text { layer }\end{array}$} & Scope & $0.87 \sim 5.10$ & $0.70-2.19$ & $8.40-22.60$ & $0.93-3.22$ & $0.080-0.24$ & $0.012-0.089$ \\
\hline & & Average & 1.84 & 1.34 & 13.96 & 2.02 & 0.16 & 0.042 \\
\hline & \multirow{2}{*}{$10 \mathrm{~m}$} & Scope & $0.84-2.58$ & $0.91-2.14$ & $9.80-21.40$ & $1.15-2.52$ & $0.09-0.230$ & $0.015-0.084$ \\
\hline & & Average & 1.69 & 1.38 & 15.37 & 1.87 & 0.15 & 0.042 \\
\hline & \multirow{2}{*}{$\begin{array}{c}\text { Bottom } \\
\text { layer }\end{array}$} & Scope & $0.91-2.79$ & $0.77-2.11$ & $8.00-21.50$ & $0.93-2.92$ & $0.080-0.23$ & $0.0070-0.11$ \\
\hline & & Average & 1.82 & 1.45 & 15.11 & 1.95 & 0.15 & 0.045 \\
\hline
\end{tabular}

Compared with relevant studies on domestic sea areas in China, the measured values in this survey are similar to those of Liaodong Bay, and lower than those of other sea areas (Table 4). In general, there is no significant difference in the average values of 6 heavy metals in seawater in May and in September, which means that the concentrations of heavy metals in seawater is relatively stable. In terms of the vertical distribution, the distribution law of the 6 heavy metals is basically the same, and they are evenly distributed in vertical dimension. It may be related to water depth and relatively uniform vertical mixing.

Table 4. Concentrations of heavy metals in seawater of different areas in China ( $\left.\mu \mathrm{g} \mathrm{L}^{-1}\right)$

\begin{tabular}{|c|c|c|c|c|c|c|c|}
\hline Area & $\mathrm{Cu}$ & $\mathrm{Pb}$ & $\mathrm{Zn}$ & $\mathrm{Cr}$ & $\mathrm{Cd}$ & $\mathrm{Hg}$ & eferences \\
\hline \multirow{2}{*}{$\begin{array}{l}\text { Liaodong Bay's } \\
\text { surface layer }\end{array}$} & $1.01-3.40$ & $0.38-3.21$ & $7.57-22.13$ & - & $0.14-0.96$ & $0.03-0.05$ & \multirow{2}{*}[16]{} \\
\hline & $1.09-2.85$ & $0.18-1.66$ & $6.70-19.73$ & - & $0.22-0.90$ & $0.04-0.06$ & \\
\hline Tianjin coastal area & $2.47-8.27$ & $2.21-8.26$ & $5.26-70.32$ & - & $0.06-0.26$ & - & {$[17]$} \\
\hline $\begin{array}{l}\text { Bohai Bay's } \\
\text { surface layer }\end{array}$ & $9.39-39.37$ & $0.062-3.69$ & $17.36-31.86$ & $3-5.89$ & $0.004-0.193$ & $0.010-0.060$ & \multirow{2}{*}[18]{} \\
\hline $\begin{array}{l}\text { Bohai Bay's } \\
\text { bottom layer }\end{array}$ & $3.27-39.37$ & $0.022-3.00$ & $9.66-68.19$ & $\begin{array}{l}2.47- \\
5.89\end{array}$ & $0.028-0.190$ & $0.012-0.060$ & \\
\hline Western Bohai Bay & $0.92-6.06$ & $0.15-1.02$ & $14.1-43.4$ & - & $0.015-0.060$ & $\begin{array}{c}0.022- \\
0.078\end{array}$ & [19] \\
\hline Qinzhou Bay & $0.55-6.90$ & $0.09-8.10$ & $1.4-43$ & $0.2-2.1$ & $0.07-0.48$ & $\begin{array}{l}0.0005- \\
0.3000\end{array}$ & {$[20]$} \\
\hline $\begin{array}{l}\text { Fangcheng Port's } \\
\text { coastal area }\end{array}$ & $1.76-4.79$ & $0.59-2.75$ & $16.9-24.9$ & $\begin{array}{c}0.55- \\
1.72\end{array}$ & $0.013-0.391$ & $0.012-0.088$ & {$[21]$} \\
\hline Port of Zhanjiang & $1.15-7.55$ & $0.57-1.19$ & $10.9-26.5$ & & $0.383-1.05$ & - & {$[22]$} \\
\hline
\end{tabular}

-: non-detected

The distribution of heavy metals in the seawater surface layer at different seasons is shown in Figure 2 and Figure 3. In May, the distribution of concentrations of $\mathrm{Cd}$ and $\mathrm{Pb}$ are similar, with the higher values in the southeast, while the higher value of $\mathrm{Hg}$ and $\mathrm{Cr}$ respectively in the middle area and in the northwest, the higher value of $\mathrm{Cu}$ dispersedly distributed. In October, the higher value of $\mathrm{Cd}$ and $\mathrm{Zn}$ is distributed in the middle area, the $\mathrm{Hg}$ in the south, while $\mathrm{Cu}, \mathrm{Cr}$ and $\mathrm{Pb}$ dispersedly distributed. There are several ports in the survey sea area, including Jinzhou Port, Huludao Port and Yingkou Port in the northwest, as well as temporary tide-bound anchorage, lying anchorage, pilot \&quarantine anchorage, barge transfer anchorage, No.1 anchorage, No.2 anchorage and other anchorages in Jingzhou Port, and many customary routes entering 
Liaodong Bay and ports. As a result, the sailing of fishery vessels and transportation vessels may be the reason for the local high concentration of heavy metals in the survey area.
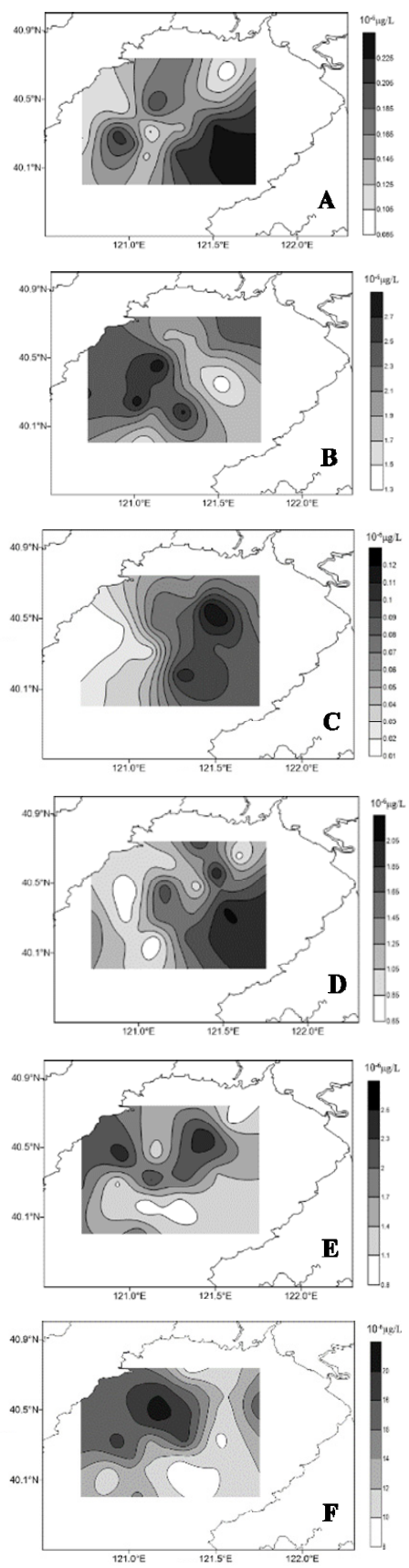

Fig.2. Distributions of heavy metals in surface seawater of investigated areas in May (A. Cd; B. Cr; C. Hg; D. Pb; E. Cu; F. Zn).

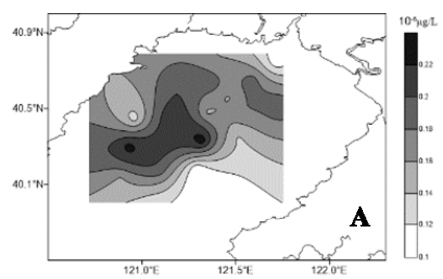

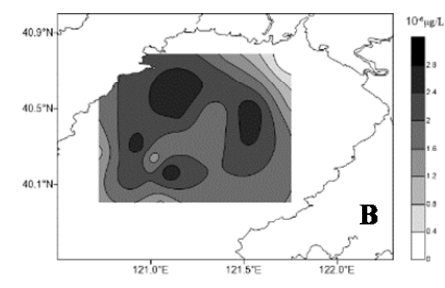
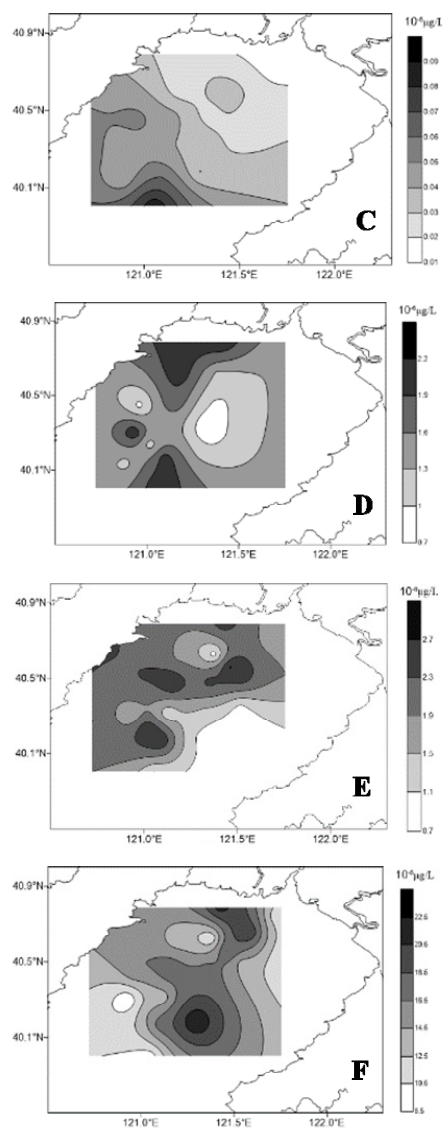

Fig.3. Distributions of heavy metals in surface seawater of investigated areas in October (A. Cd; B. Cr; C. Hg; D. Pb; E. $\mathrm{Cu} ; \mathrm{F} . \mathrm{Zn})$.

\subsection{Distribution characteristics of heavy metals in sediments}

The values of concentrations of heavy metals in the sediment samples from the survey sea area are shown in Table 5. In May, the average values of these 6 heavy metals are respectively: $\mathrm{Cu}: 17.35 \mu \mathrm{g} \mathrm{L}^{-1}$; $\mathrm{Pb}: 14.04 \mu \mathrm{L} \mathrm{L}^{-1}$; $\mathrm{Zn}: 22.21 \mu \mathrm{g} \mathrm{L}^{-1}$; Cr: $20.53 \mu \mathrm{g} \mathrm{L}{ }^{-1}$ : Cd: $0.13 \mu \mathrm{g} \mathrm{L}^{-1}$; $\mathrm{Hg}$ : $0.041 \mu \mathrm{g} \mathrm{L}^{-1}$. In October, the average values of these 6 heavy metals are respectively: $\mathrm{Cu}: 27.03 \mu \mathrm{g} \mathrm{\textrm {L } ^ { - 1 }}$; $\mathrm{Pb}$ : $19.96 \mu \mathrm{g} \mathrm{L}^{-1} ; \mathrm{Zn}: 102.70 \mu \mathrm{g} \mathrm{L}^{-1}$; Cr: $20.93 \mu \mathrm{g} \mathrm{L}^{-1} ; \mathrm{Cd}$ : $0.79 \mu \mathrm{g} \mathrm{L}^{-1} ; \mathrm{Hg}: 0.15 \mu \mathrm{g} \mathrm{L}^{-1}$. Compared with relevant studies on surface layer sediments in the domestic sea areas of China, the values in this survey are similar to the analysis results of heavy metals in sediments sampled from Liaodong Bay, with lower concentrations of $\mathrm{Pb}, \mathrm{Cd}$ and Hg. While, compared with other areas of Bohai Bay, the content values of $\mathrm{Cu}, \mathrm{Cd}$ and $\mathrm{Hg}$ in this survey sea area are relatively high (Table 6). Compared with other sea areas such as Zhanjiang Bay, the content values of heavy metals in spring are not high, while the concentrations of $\mathrm{Cd}$ and $\mathrm{Hg}$ in autumn are much higher. 
According to the comparison of values of heavy metals in sediments detected from different bays in the Bohai Sea, some scholars find that the content values of $\mathrm{Cu}, \mathrm{Cd}$ and $\mathrm{Hg}$ the in the sediments of Liaodong Bay are relatively high ${ }^{[23]}$. In terms of seasonal changes, the average concentration of heavy metal in the surface layer sediments is generally higher in autumn than in spring, except for $\mathrm{Cr}$ (Table 5).

Table 5. Concentrations of heavy metals in sediments $\left(\mu \mathrm{g} \mathrm{L}^{-1}\right)$

\begin{tabular}{|c|c|c|c|c|c|c|c|}
\hline Time & Value & $\mathrm{Cu}$ & $\mathrm{Pb}$ & $\mathrm{Zn}$ & $\mathrm{Cr}$ & $\mathrm{Cd}$ & $\mathrm{Hg}$ \\
\hline \multirow{2}{*}{ May } & Scope & $12.6-25.80$ & $10.1-19.70$ & $15.7-26.90$ & $14.40-27.20$ & $0.063-0.23$ & $0.020-0.057$ \\
\hline & Average & 17.35 & 14.04 & 22.21 & 20.53 & 0.13 & 0.041 \\
\hline \multirow[t]{2}{*}{ October } & Scope & $14.7-40.90$ & $10.8-44.20$ & $50.30-250.00$ & $10.40-43.20$ & $0.074-4.09$ & $0.034-0.67$ \\
\hline & Average & 27.03 & 19.96 & 102.70 & 20.93 & 0.79 & 0.15 \\
\hline
\end{tabular}

Table 6. Concentrations of heavy metals in sediments of different areas in China ( $\mu \mathrm{g} \mathrm{L-1)}$

\begin{tabular}{|c|c|c|c|c|c|c|c|c|}
\hline Sea Area & Time & $\mathrm{Cu}$ & $\mathrm{Pb}$ & $\mathrm{Zn}$ & $\mathrm{Cr}$ & $\mathrm{Cd}$ & $\mathrm{Hg}$ & $\begin{array}{c}\text { Referenc } \\
\text { es }\end{array}$ \\
\hline $\begin{array}{c}\text { Western } \\
\text { Liaodong Bay }\end{array}$ & 2009.5 & 15. $9-32.1$ & $23.3-56.9$ & $40.6-102.6$ & - & $0.12-0.22$ & - & {$[8]$} \\
\hline Liaodong Bay & - & $0.24-58.5$ & $1.13-66.1$ & $11.4-251.04$ & $0.049-188$ & $0.0245-38.8$ & $0.0019-2.72$ & {$[22]$} \\
\hline $\begin{array}{c}\text { North } \\
\text { Liaodong Bay }\end{array}$ & 2017.8 & $22.39-33.79$ & $14.45-33.37$ & $\begin{array}{l}45.02- \\
125.85\end{array}$ & - & $0.11-0.46$ & $0.03-0.07$ & {$[23]$} \\
\hline $\begin{array}{l}\text { Beidaihe } \\
\text { coastal area }\end{array}$ & 2011.5 & $10.5-20.7$ & $11.4-27.4$ & $28.3-70.6$ & - & - & - & [24] \\
\hline Qinhuangdao & $\begin{array}{l}2009 \\
\text { spring }\end{array}$ & - & $6.6-35.4$ & $1.5-96.0$ & - & $0.025-0.255$ & $0-0.21$ & {$[25]$} \\
\hline $\begin{array}{c}\text { Caofeidian sea } \\
\text { area }\end{array}$ & 2014.9 & $12.2-17.7$ & $14.6-23.5$ & $45.5-89.5$ & - & $0.15-0.25$ & $0.049-0.082$ & {$[26]$} \\
\hline $\begin{array}{c}\text { Tianjin sea } \\
\text { area }\end{array}$ & 2005.5 & 27.2 & 25.00 & 94.3 & - & 0.15 & 0.050 & {$[27]$} \\
\hline $\begin{array}{c}\text { Western Bohai } \\
\text { Sea }\end{array}$ & 2004.10 & $9.82-38.99$ & $0.81-4.97$ & $5.16-137.1$ & - & $0.05-0.17$ & $0.01-0.16$ & [18] \\
\hline Laizhou Bay & 2014.10 & $18.1-26.9$ & $9.6-30.9$ & $17.3-30.8$ & $15.0-26.3$ & $0.01-0.194$ & $0.027-0.068$ & {$[28]$} \\
\hline Jiaozhou Bay & 2015.5 & $12.97-37.72$ & $8.81-33.93$ & $37.00-87.92$ & $\begin{array}{l}32.59- \\
62.73\end{array}$ & $0.108-0.257$ & - & [29] \\
\hline $\begin{array}{c}\text { North Haizhou } \\
\text { Bay }\end{array}$ & 2014.10 & $3.23-30.69$ & $21.22-43.28$ & $15.6-122.1$ & $\begin{array}{l}10.58- \\
77.01\end{array}$ & $0.07-0.15$ & 0.002-0.009 & {$[30]$} \\
\hline Zhanjiang Bay & 2010.5 & $19.18-38.78$ & $43.44-64.08$ & $76.30-134.4$ & $\begin{array}{l}72.58- \\
95.17\end{array}$ & $0.120-0.296$ & - & {$[31]$} \\
\hline $\begin{array}{l}\text { South sea area } \\
\text { of Hainan } \\
\text { Island }\end{array}$ & 2015 & $0.9-19.26$ & $11.33-43.05$ & $4.59-94.13$ & $3.07-60.74$ & $0.01-0.14$ & - & {$[32]$} \\
\hline
\end{tabular}

$\therefore$ non-detected

The distribution of heavy metals in sediments is shown in Figure 4 and Figure 5. In spring, the high value of $\mathrm{Cr}$ and $\mathrm{Cu}$ are located in the middle area, and $\mathrm{Cd}$ and $\mathrm{Pb}$ are discretely distributed. The high values of $\mathrm{Zn}$ and $\mathrm{Hg}$ are distributed in the north, which means that they may come from terrestrial sources. In Autumn, the high value of $\mathrm{Cr}$ is distributed in the north and the south, while the distribution of other heavy metals shoe the trend of gradual decrease from near coast to far coast, indicating that the heavy metals in the sediments may mainly come from terrestrial sources. After summarizing the studies on the distribution and sources of heavy metals in the Bohai Sea, some scholars find that most of the heavy metals in the Bohai Sea sediments are transferred from river flows ${ }^{[1]}$. Some studies have proven that concentration of heavy metal discharged into rivers is significantly positively correlated with heavy metal content in sediments one year later, which means that the discharge of heavy metal from terrestrial sources can significantly affect the change of content of heavy metals in sediments ${ }^{[34]}$. The distribution characteristics of concentration value of heavy metals in sediments in the survey sea area is obvious in autumn, with most concentrated in the vicinity of Jinzhou Bay. According to 2016 Communique on the Environ. Quality of the Offshore Area in China and Communique on Marine Environment Quality of North China Sea Waters, the concentration of heavy metals in Jinzhou area is 
relatively high. Since this area is surrounded by land, such high concentration of heavy metals can be attributed to the relatively intensive coastal industrial distribution. The industrial saltwater and domestic sewage generated on the land will flow into the sea along with river flows, combined with the influence of coastal flow in autumn, the above distribution characteristics are available.
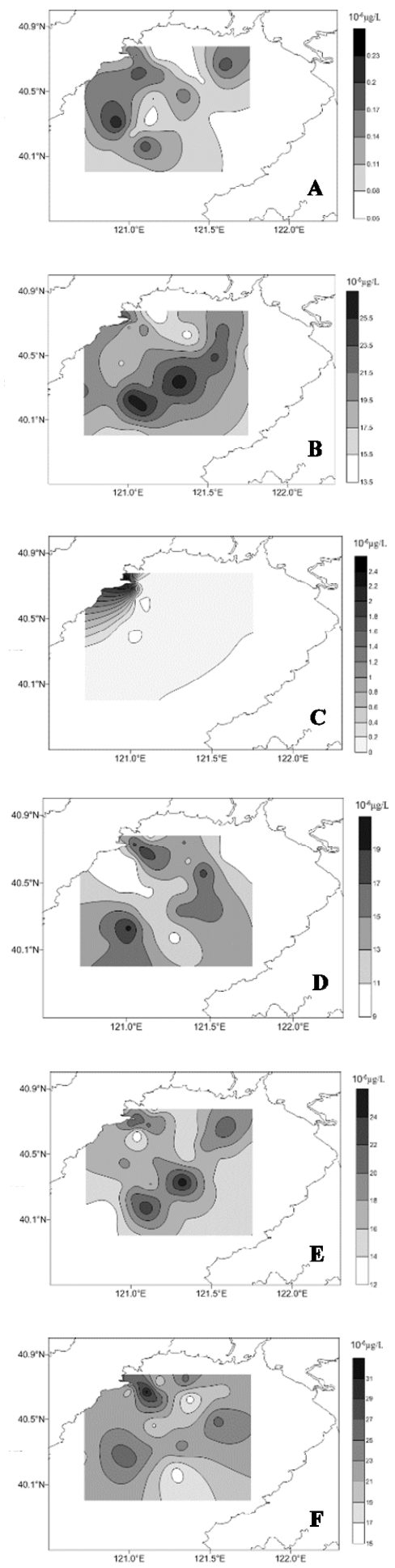

Fig.4. Distributions of heavy metals in sediments of investigated areas in spring (A. Cd; B. Cr; C. Hg; D. Pb; E. Cu; F. Zn).
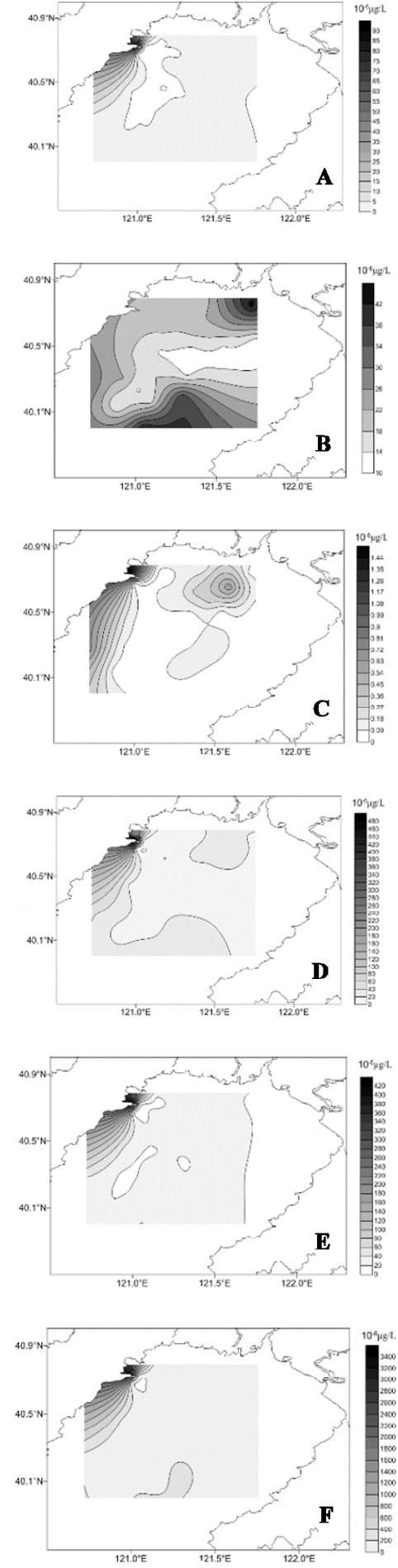

Fig.5. Distributions of heavy metals in sediments of investigated areas in autumn (A. Cd; B. Cr; C. Hg; D. Pb; E. $\mathrm{Cu} ; \mathrm{F} . \mathrm{Zn})$.

According to the correlation analysis, there is significant positive correlation among these heavy metals, which means that these heavy metals have similar migration and transformation behaviors and the same sources (Table 7). At the same time, all these heavy metals are significantly positive correlated with total organic carbon (TOC), namely, along with the increase of organic content, heavy metal content also increases. Studies show that organic matter is an important factor affecting heavy metal content in 
sediments, since organic matter can adsorb heavy metals through complexation, and finally lead to the increase of heavy metal content in sediments ${ }^{[35,36]}$.

Table 7. Correlations of heavy metals and TOC in sediments

\begin{tabular}{ccccccc}
\hline & $\mathrm{Cr}$ & $\mathrm{Cd}$ & $\mathrm{Hg}$ & $\mathrm{Pb}$ & $\mathrm{Cu}$ & $\mathrm{Zn}$ \\
\hline $\mathrm{TOC}$ & $0.907^{* *}$ & $0.911^{* *}$ & $0.575^{* *}$ & $0.864^{* *}$ & $0.908^{* *}$ & $0.907^{* *}$ \\
$\mathrm{Cr}$ & & $0.982^{* *}$ & $0.431^{*}$ & $0.921^{* *}$ & $0.989^{* *}$ & $0.993^{* *}$ \\
$\mathrm{Cd}$ & & & $0.411^{*}$ & $0.975^{* *}$ & $0.995^{* *}$ & $0.993^{* *}$ \\
$\mathrm{Hg}$ & & & & $0.382^{*}$ & $0.420^{*}$ & $0.418^{*}$ \\
$\mathrm{~Pb}$ & & & & & $0.956^{* *}$ & $0.946^{* *}$ \\
$\mathrm{Cu}$ & & & & & & $0.998^{* *}$ \\
\hline
\end{tabular}

** means $\mathrm{p}<0.001 ; *$ means $\mathrm{p}<0.01$

Compared with the concentration of heavy metals in the sediments, the concentration of heavy metals in the seawater from the survey area is lower. Although the distribution of some heavy metals in the surface layer seawater and surface layer sediments in this survey shows a trend of gradual decrease from the coast to the sea. However, according to the correlation analysis on the concentration of these 6 heavy metals in surface layer seawater and surface layer sediments, there is no significant correlation between them, namely, there is no direct correlation between their concentration and distribution changes.

There are multiple anchorages and sea-routes in the survey area, and frequent sailing of fishery vessels and transportation vessels may be factors affecting the change of heavy metal concentration in the survey area. At the same time, the complexity of heavy metal migration and transformation in marine environment is usually the result of many factors. In terms of the discussion on the influence of bioturbation on the distribution of heavy metals in sediments, some studies point out that the bioturbation via particle reconstruction and cave flushing can drive heavy metals to migrate between the water phase and the surface layer of sediments [37]. Furthermore, factors affecting the migration and transformation distribution of heavy metals in sediments, including sulfide, acid volatile sulfide, organic components, sediment substratum, $\mathrm{pH}$, redox potential and hydrodynamics are need to be considered ${ }^{[38]}$.

\subsection{Pollution evaluation}

Such evaluation is carried out according to the first-class quality standards of seawater and sediments, with the evaluation results shown in Table 8 and Table 9.

Table 8. Single factor index of heavy metals in seawater

\begin{tabular}{|c|c|c|c|c|c|c|c|c|}
\hline Season & $\begin{array}{c}\text { Depth of } \\
\text { water }\end{array}$ & Value & $\mathrm{Cu}$ & $\mathrm{Pb}$ & $\mathrm{Zn}$ & $\mathrm{Cr}$ & $\mathrm{Cd}$ & $\mathrm{Hg}$ \\
\hline \multirow{9}{*}{ Spring } & \multirow{3}{*}{ Surface layer } & Scope & $0.17-0.52$ & $0.66-2.36$ & $0.42-1.14$ & $0.02-0.06$ & $0.03-2.13$ & $0.28-3.64$ \\
\hline & & Average & 0.36 & 1.42 & 0.77 & 0.04 & 0.14 & 1.32 \\
\hline & & $>$ Class I & - & $46.67 \%$ & $13.33 \%$ & - & - & $60.00 \%$ \\
\hline & \multirow{3}{*}{$10 \mathrm{~m}$} & Scope & $0.19-0.56$ & $0.02-2.10$ & $0.03-1.14$ & $0.02-0.06$ & $0.08-0.23$ & $0.07-2.40$ \\
\hline & & Average & 0.34 & 0.83 & 0.51 & 0.04 & 0.16 & 0.83 \\
\hline & & $>$ Class I & - & $37.78 \%$ & $8.89 \%$ & - & - & $31.11 \%$ \\
\hline & \multirow{3}{*}{ Bottom layer } & Scope & $0.19-0.56$ & $0.73-2.12$ & 0.46-1.09 & $0.02-0.06$ & $0.09-0.23$ & $0.38-1.95$ \\
\hline & & Average & 0.39 & 1.43 & 0.77 & 0.04 & 0.15 & 0.94 \\
\hline & & $>$ Class I & - & $81.48 \%$ & $11.11 \%$ & - & - & $33.33 \%$ \\
\hline \multirow{8}{*}{ Autumn } & \multirow{3}{*}{ Surface layer } & Scope & $0.17-0.52$ & $0.66-2.36$ & $0.42-1.14$ & $0.02-0.06$ & $0.03-2.13$ & $0.28-3.64$ \\
\hline & & Average & 0.36 & 1.42 & 0.77 & 0.04 & 0.14 & 1.32 \\
\hline & & $>$ Class I & - & $46.67 \%$ & $13.33 \%$ & - & - & $60.00 \%$ \\
\hline & \multirow{3}{*}{$10 \mathrm{~m}$} & Scope & $0.17-1.02$ & $0.70-2.19$ & $0.42-1.13$ & $0.00-0.06$ & $0.08-0.24$ & $0.20-1.77$ \\
\hline & & Average & 0.40 & 1.44 & 0.76 & 0.04 & 0.17 & 0.70 \\
\hline & & $>$ Class I & - & $85.11 \%$ & $17.02 \%$ & - & - & $14.89 \%$ \\
\hline & \multirow[b]{2}{*}{ Bottom layer } & Scope & $0.02-1.02$ & $0.10-2.19$ & $0.10-1.13$ & $0.00-0.06$ & $0.01-0.23$ & $0.05-1.77$ \\
\hline & & $\begin{array}{l}\text { Average } \\
>\text { Class I }\end{array}$ & $\begin{array}{c}0.36 \\
-\end{array}$ & $\begin{array}{c}1.57 \\
42.55 \%\end{array}$ & $\begin{array}{c}0.78 \\
4.26 \%\end{array}$ & $\begin{array}{c}0.033 \\
-\end{array}$ & $\begin{array}{c}0.16 \\
-\end{array}$ & $\begin{array}{c}0.76 \\
8.51 \%\end{array}$ \\
\hline
\end{tabular}

-: non-detected

Table 9. Single Factor Index of Heavy Metals in Sediments

\begin{tabular}{cccccccc}
\hline & Scope & $\mathrm{Cu}$ & $\mathrm{Pb}$ & $\mathrm{Zn}$ & $\mathrm{Cr}$ & $\mathrm{Cd}$ & $\mathrm{Hg}$ \\
\hline \multirow{3}{*}{ Spring } & Scope & $0.36-0.74$ & $0.18-0.30$ & $0.10-0.17$ & $0.18-0.34$ & $0.13-0.38$ \\
& Average & 0.49 & 0.23 & 0.15 & 0.26 & $0.10-0.69$ \\
& $>$ Class I & - & - & - & - & -
\end{tabular}




\begin{tabular}{ccccccccc} 
& Scope & $0.42-1.17$ & $0.15-0.74$ & $0.35-1.67$ & $0.13-0.54$ & $0.15-8.18$ & $0.17-3.33$ \\
\multirow{2}{*}{ Autumn } & Average & 0.77 & 0.33 & 0.69 & 0.26 & 1.59 & 0.77 \\
& $>$ Class I & $23.81 \%$ & - & $19.05 \%$ & - & $28.57 \%$ & $19.05 \%$ \\
\hline
\end{tabular}

-: non-detected

The contents of $\mathrm{Cu}, \mathrm{Cr}$ and $\mathrm{Cd}$ in the seawater of the survey sea area meet the first-class seawater quality standard. The contents of $\mathrm{Pb}, \mathrm{Zn}$ and $\mathrm{Hg}$ in both two seasons exceed the Class I seawater quality standard, and meet Class II seawater quality standard. Moreover, seawater at the bottom layer exceeding the Class I standard accounts for high proportion.

According to the single factor index, the sediment quality in the survey sea area is good in spring and no values have been measured at any station exceeding Class I standards. The standard index in autumn shows that $\mathrm{Cu}$ exceeds the Class I standard and meets Class II standard. $\mathrm{Zn}, \mathrm{Cd}$ and $\mathrm{Hg}$ all exceed Class I standards and meet Class III standards.

\subsection{Potential ecological risk assessment of heavy metals in sediments}

In this paper, the potential ecological risk index evaluation method on heavy metals proposed by Hakanson (1980) has been adopted to evaluate the potential ecological risk of sediments in the surveyed sea area ${ }^{[14]}$, with the potential ecological risk coefficient Eri shown in Table 10. $E_{r}{ }^{i}$ values of these 6 heavy metals in spring can be graded from high value to low value, namely, $\quad \mathrm{Hg}>\mathrm{Cd}>\mathrm{Cu}>\mathrm{Pb}>\mathrm{Cr}>\mathrm{Zn}$, while $\mathrm{Cd}>\mathrm{Hg}>\mathrm{Cu}>\mathrm{Pb}>\mathrm{Zn}>\mathrm{Cr}$ in autumn. It shows that $\mathrm{Hg}, \mathrm{Cd}$ and $\mathrm{Cu}$ are suffering from high potential ecological risks in the survey sea areas, which is similar to the results of research on Liaodong Bay ${ }^{[11]}$. According to multiple studies, heavy metal pollutants in the Liaodong Bay mostly come from the surrounding rivers flowing into the sea ${ }^{[12]}$. Considering many anchorages and customary routes in Liaodong Bay, great attention should also be paid to the vessel pollution.

Table 10. Potential ecological risk factors of heavy metals in the sediments $\left(E_{r}^{i}\right)$

\begin{tabular}{cccccccc}
\hline \multirow{2}{*}{ Season } & Value & $\mathrm{Cu}$ & $\mathrm{Pb}$ & $\mathrm{Zn}$ & $\mathrm{Cr}$ & $\mathrm{Cd}$ & $\mathrm{Hg}$ \\
\hline \multirow{2}{*}{ Spring } & Scope & $2.52-5.16$ & $1.68-3.28$ & $0.20-0.34$ & $0.48-0.91$ & $3.79-13.62$ & $3.90-27.60$ \\
& Average & 3.47 & 2.34 & 0.28 & 0.68 & 6.99 & 8.28 \\
& Scope & $2.94-8.18$ & $1.50-7.37$ & $0.63-3.13$ & $0.42-1.44$ & $4.43-245.40$ & $7.26-133.00$ \\
\multirow{2}{*}{ Autumn } & Average & 5.41 & 3.33 & 1.28 & 0.70 & 47.68 & 30.7 \\
& & \multicolumn{5}{c}{ Sin., $\mathbf{4 0}(6): 60-73(2018)}$.
\end{tabular}

\section{References}

1. L. Guo, G.H. Wu, J.M. Shang. Mar. Environ. Sci, 33(1): 169-176 (2014).

2. Q.Y. Yu, Y. Wang, Y. Xu, et al. Asian J. Ecotoxicol., 8(4): 504-512 (2013).

3. H.W. Qin, A.Y. Liu, W.L. Gu, et al. Asian J. Ecotoxicol., 10(6):287-296 (2015).

4. X. Chen, S.Z. Li, D.K. Yuan, et al. Adv. in Mar. Sci., 35(3): 382-391 (2017).

5. C. Liu, L.F. Chen, H.Y. Gao, et al. J. Ocean Uni. China, 48(S2): 59-66 (2018).

6. N.J. Hu, X.F. Shi, P. Huang, et al. China Environ. Sci., 30(3): 380-388 (2010).

7. X.H. Lan, X.J. Meng, X. Mei, et al. Mar. Geol. Front., 32(5): 48-53 (2016).

8. Q.B. Sun, Y.Z. Chen, L.Y. Sun, et al. J. Appl. Oceanol., 34(1): 73-79 (2015).

9. X.R. Zhang, Y. Zhang, Q. Ye, et al. Mar. Geol. Quat. Geol., 32(2): 21-29 (2012).

10. Y.E. Bao, W.X. Fu. Acta Oceanol. Sin., 16(3):139142 (1994).

11. X.H. Lan, X.J. Meng, X. Mei, et al. Acta Oceanol.
12. J. Wu, F. Guo. J. Environ. Eng. Tech., 8(1): 65-70 (2018).

13. Y.N. Huang, S.M. Pan, K.X. Zhang, et al. Mar. Geol. Quat. Geol., 38(4): 32-43 (2018).

14. L. Hakanson. Water Research, 14: 975-1001 (1980).

15. M.H. Feng, J.P. Long, L. Yu, et al. Mar. Sci., 27(3): 52-56 (2003).

16. Y.G. Song, J.H. Wu, Z.W. Shao. Pro. Fishery Sci., 37(3): 14-19 (2016).

17. H.W. Wang, Y.Z. Qiao, L.P. Wang. J. Hydro., 38(2): 38-43 (2017).

18. D.B. Cai, L.K. Yang, N. Zhu, et al. J. Hebei Uni. (Natural Sci. Edition), 35(4):371-384 (2015).

19. X.L. Zhang, D.W. Ding, J.S. Xu. J. east China Inst. Technol., 33(3): 276-280 (2010).

20. X.Q. Huang, J.Q. Lin, S.Z. Zhang, et al. Mar. Environ. Sci., 32(5): 729-762 (2013).

21. X.Y. He. J. Anhui Agri. Sci., 42(23): 7956-7959 (2014,).

22. Z.Q. Yi, Y.W. Yang, J.B. Zhang, et al. J. Guangdong Ocean Uni., 31(1): 73-79 (2011).

23. Y. Xu, Q.L. Wang, X. Li, et al. Advances in Mar. Sci., 35(3): 428-438 (2017). 
24. L.P. Che. Hebei Fisheries, 292(4): 36-40 (2018).

25. X.Y. Li, Y.F. Zhang, Z.C. Fan, et al. Environ. Sci. Sur., 33 (3): 62-72 (2014).

26. Q.D. Han, Z.W. Li. J. Anhui Agri. Sci., 39(26): 16074-16075 (2011).

27. W. Wang, M.W. Jun, D.P. Li, et al. Ocean Devel. Manag., 7:72-76 (2018).

28. S.N. Zhang, J.C. Tang. Mar. Sci. Bull., 153(2):85-90 (2008).

29. Q. Hu, Q. Li, B.G. Huang, et al. Pro. Fishery Sci., 38(2): 16-23 (2017).

30. C.L. Xiao, L.F. Chen, Y.B.Li. China Sci. paper, 12(9): 1079-1086 (2017).

31. K. Meng, M. Xu, W.J. Xu, et al. J. Nangjing Normal Uni. ( Natural Sci. Edition), 41(2):99-106 (2018).

32. J.B. Zhang, J.F. Liu, C.X. Zhang, et al. Mar. Environ. Sci., 31(5): 644-648 (2012).

33. K. Luo, L. Li, G.Y. Long, et al. J. Shanghai Ocean Uni, 26(1): 85-93 (2017).

34. S.X. Huo, C.C. Xing, C.Q. Zhu, et al. J. Ocean Uni of China, 47(10): 42-49 (2017).

35. Y.B. Li, Y. Cai. J. Environ. Sci., 31(5): 203-205 (2015).

36. W.L. Wang, J.G. Wang, C. Lin, et al. J. of Appl. Oceano., 35(2): 284-293 (2016).

37. Y. He, B. Men, X.F. Yang, et al. Asian J. Ecotoxicol. 11(6): 25-36 (2016).

38. Y.H. Deng, J. Zhao. Environ. Eng., 35(4): 179-182 (2017). 